\title{
PENGEMBANGAN PEMBELAJARAN MATERI MUAMALAH DENGAN MENGGUNAKAN BLOG PION
}

\author{
Alfiyanti Rohmah*, Izzatul Mardhiah, Rihlah Nur Aulia \\ Universitas Negeri Jakarta, Indonesia \\ *E-mail: alfiyantirohmah_pai16s1@mahasiswa.unj.ac.id
}

\begin{abstract}
This research aims to develop Blog PION as a learning media based on blended learning on Muamalah material. This type of research is Research and Development with ADDIE models. Data is presented in the form of descriptive data. Data collection techniques used were interviews and questionnaires. The results of this study indicate that 1) The first stage is an analysis of the curriculum, media and learning models that have been used, and materials that need to be studied by students, 2) The design of Blog PION is done by designing and setting product titles, making storyboards, and making product display, 3) Making a blog through WordPress and supporting images using Adobe Illustrator CS6, 4) Implementation by validating the material and media contained in the PION Blog and evaluating teachers and students, 5). Evaluated according to the advice of material experts and media experts as well as weighing the advantages and disadvantages of PION Blog.
\end{abstract}

Keywords: Learning Media, Blog, Muamalah

Abstrak. Penelitian ini bertujuan untuk mengembangkan Blog PION sebagai media pembelajaran berbasis blended learning pada materi Muamalah. Jenis penelitian ini adalah Research and Development dengan model ADDIE. Data disajikan dalam bentuk deskriptif data. Teknik pengumpulan data yang digunakan adalab wawancara serta penyebaran angket. Hasil penelitian ini menunjukkan bahwa 1) Tahap pertama dilakukan analisis terbadap kurikulum, media dan model pembelajaran yang telah digunakan, dan materi yang perlu dipelajari oleh peserta didik, 2) Desain Blog PION dilakukan dengan cara merancang dan menetapkan judul produk, membuat storyboard, serta membuat tampilan produk, 3) Pembuatan blog melalui WordPress dan gambar penunjang menggunakan Adobe Illustrator CS6, 4) Implementasi dengan cara melakukan validasi materi dan media yang terdapat dalam Blog PION serta penilaian guru dan peserta didik, 5). Dilakukan evaluasi sesuai dengan saran abli materi dan abli media serta menimbang kelebihan dan kekurangan Blog PION.

Kata Kunci: Media Pembelajaran, Blog, Muamalah 


\section{PENDAHULUAN}

Salah satu produk perkembangan zaman yang menawarkan hal-hal baru pada berbagai bidang kehidupan manusia adalah teknologi informasi dan komunikasi. Pesatnya kemajuan teknologi ini kian memudahkan pekerjaan manusia, misalnya dalam hal mengakses informasi. Beberapa teknologi yang memudahkan pekerjaan manusia dalam hal mengakses informasi adalah website, blog, artikel, micro blogging site, koran online, dan lain sebagainya (Chaidar, 2014).

Teknologi informasi dan komunikasi juga memiliki peran dalam bidang pendidikan dan turut berinteraksi erat dengan peserta didik. Misalnya, peserta didik yang dihadapi oleh guru saat ini memiliki kecenderungan terhadap penggunaan teknologi informasi dan komunikasi (TIK) dalam proses pembelajaran seperti mengakses media pembelajaran secara daring dengan menjelajahi situs-situs yang ada di internet untuk menunjang proses pembelajaran (Suhartono, 2017).

Dalam pengalaman peneliti ketika Praktek Keterampilan Mengajar di sekolah pada mata pelajaran Pendidikan Agama Islam dan Budi Pekerti, peserta didik terbukti memiliki kecenderungan mengakses situs-situs yang terdapat di internet. Ketika diberikan soal atau tugas, peserta didik lebih memilih untuk mencari jawabannya di internet daripada buku cetak yang telah difasilitasi oleh sekolah. Situs internet yang dijadikan bahan rujukan peserta didik belum jelas asal usulnya serta materi yang terdapat dalam situs tersebut belum tentu benar. Terlebih bila peserta didik tidak bertatap langsung dengan guru, sehingga materi yang diperoleh dari internet tidak bisa dipantau atau dipastikan kebenarannya oleh guru secara langsung.

Sebagai seorang muslim, peserta didik diharapkan mampu menerapkan apa yang diajarkan oleh Islam dalam berbagai bidang kehidupan, termasuk dalam ajaran mengenai muamalah. Sebab muamalah merupakan ketentuan yang telah Allaah berikan dan harus diaplikasikan dalam kehidupan bermasyarakat agar terjaganya kepentingan hidup manusia. Muamalah juga sering dipahami hanya sebatas diperbolehkannya jual beli dan diharamkannya riba, sedangkan bahasan muamalah tidak hanya itu. Sehingga peserta didik harus memiliki konsep dan pemahaman yang benar agar tidak salah dalam mempraktikkannya dalam kehidupan sehari-hari.

Pada era digital seperti ini, peserta didik mudah untuk mengakses media pembelajaran salah satunya melalui internet. Situs di internet yang diakses oleh peserta didik, belum dapat dipastikan satu persatu kebenarannya. Maka dari itu, diperlukan referensi dengan materi dan media pembelajaran yang tervalidasi. Pembelajaran dengan materi muamalah melalui akses internet perlu dirancang serta disusun lebih baik lagi supaya materi yang disampaikan dapat dicerna dengan baik oleh peserta didik.

Bertalian dengan apa yang telah dipaparkan di atas, maka guru perlu berinovasi dalam memilih serta menetapkan pendekatan pembelajaran. Adapun inovasi pendekatan pembelajaran yang sesuai dengan fakta lapangan tersebut adalah pendekatan 
blended learning. Blended learning merupakan asosiasi antara pembelajaran berbasis web (web-based learning) dan pembelajaran berbasis tatap muka (face to face learning) dengan perbandingan 3:7 dalam penerapannya. Blended learning juga memberikan kesempatan pada peserta didik agar terpenuhi kuriositasnya terhadap suatu materi dalam pembelajaran tatap muka yang berlangsung di sekolah, pendalaman atau penjelajahan, dan terkoneksi dengan media belajar yang ada. Hal ini memungkinkan penggunaan media belajar secara daring (Dwi Irmawati, Sriyono, 2012).

Untuk menerapkan blended learning tersebut, maka diperlukan media pembelajaran yang mendukung proses pembelajaran berbasis blended learning. Salah satu media sederhana untuk menerapkan blended learning adalah pembuatan blog. Blog yang dimanfaatkan guru sebagai media pembelajaran, dapat digunakan sebagai perantara atau penghubung agar pesan guru kepada peserta didik (ataupun sebaliknya) dapat tersampaikan dengan baik. Blog juga dapat dimanfaatkan untuk menunjang proses pembelajaran jarak jauh, mengatasi keterbatasan dalam hal waktu untuk bertatap muka dengan peserta didik, atau untuk memperkenalkan penggunaan internet secara positif kepada peserta didik. Jika konten dari blog tersebut menarik, informatif, edukatif, maka akan semakin banyak yang mengakses situs blog yang dibuat oleh guru tersebut, sehingga jangkauannya semakin luas dan dapat diakses oleh siapapun, tidak berbatas hanya peserta didik yang diampu oleh guru tersebut.

Blended learning mulai diterapkan pada sekolah negeri maupun swasta. Pada SMK Negeri 1 Cibinong, terdapat beberapa pelajaran yang mulai menerapkan blended learning dalam proses pembelajarannya seperti mengakses blog pribadi guru, mengadakan quiz melalui Edmodo, melaksanakan Penilaian Tengah Semester (PTS) dan Penilaian Akhir Tahun (PAT) yang diselenggarakan dengan cara Computer Based Test (CBT).

Namun pada mata pelajaran Pendidikan Agama Islam dan Budi Pekerti di SMK Negeri 1 Cibinong, belum secara resmi menerapkan blended learning dalam proses pembelajarannya. Proses pembelajaran Pendidikan Agama Islam dan Budi Pekerti di sekolah ini, umumnya menggunakan model pembelajaran teacher centered dengan metode ceramah, model pembelajaran student centered dengan metode diskusi, melakukan beberapa games seperti jigsaw, mendemonstrasian atau mempraktikkan suatu materi seperti praktik shalat dan memandikan jenazah, menggunakan media sort card misalnya pada materi Asmaul Husna.

Kalender akademik yang begitu padat dan terkadang berbenturan dengan agenda sekolah atau guru berhalangan hadir, terkadang membuat materi yang seharusnya dipelajari menjadi tidak dapat tersampaikan dengan baik. Selain itu, peserta didik kelas XI yang melakukan Praktek Kerja Industri (Prakerin) atau biasa disebut dengan Praktik Kerja Lapangan (PKL), selama kurang lebih tiga bulan juga berpotensi tertinggal pelajaran dan harus mengejar materi saat 
selesai Prakerin, belum lagi harus menyelesaikan tugas akademik selama tiga bulan tersebut. Berakhirnya masa Prakerin dari masing-masing peserta didik juga tidak bersamaan karena mengingat waktu mulai Prakerinnya pun berbeda-beda. Sehingga materi yang diterima oleh masing-masing peserta didik berbeda bobotnya.

Berdasarkan hal itu, Blog PION sebagai media pembelajaran perlu diteliti untuk memperjelas tahapan pembuatannya sesuai dengan tahapan model pengembangan yang dipilih atau tidak.

Fokus penelitian ini meliputi analisis yang dilakukan sebelum pembuatan Blog PION, desain Blog PION sebagai media pembelajaran berbasis blended learning pada materi Muamalah kelas XI di SMK Negeri 1 Cibinong, proses pembuatan Blog PION sebagai media pembelajaran berbasis blended learning pada materi Muamalah kelas XI di SMK Negeri 1 Cibinong, implementasi Blog PION sebagai media pembelajaran berbasis blended learning pada materi Muamalah kelas XI di SMK Negeri 1 Cibinong, dan evaluasi terhadap Blog PION sebagai media pembelajaran berbasis blended learning pada materi Muamalah kelas XI di SMK Negeri 1 Cibinong.

\section{METODE PENELITIAN}

Penelitian ini merupakan penelitian research and development dengan model pengembangan ADDIE; Analyze, Design, Development, Implement, and Evaluate. Teknik analisis data yang digunakan adalah desktiptif data.

Uji validitas oleh ahli materi dilakukan pada 23 April 2020 dan uji validitas oleh ahli media dilakukan pada 26 April 2020. Penelitian ini dilakukan di SMK Negeri 1 Cibinong pada 23 April sampai dengan 8 Juni 2020 untuk uji implementasi blog kemudian pengisian angket penilaian guru dan pengisian angket serta wawancara peserta didik.

Instrumen yang digunakan untuk mengumpulkan data adalah wawancara dan penyebaran angket. Wawancara dilakukan untuk mengetahui respon peserta didik terhadap Blog PION. Angket berfungsi untuk mengukur kualitas blog yang dikembangkan. Instrumen angket pada penelitian ini digunakan untuk memperoleh data dari ahli media, ahli materi, guru dan peserta didik di SMK Negeri 1 Cibinong sebagai bahan evaluasi.

\section{HASIL PENELITIAN DAN PEMBAHASAN}

Kata PION dalam Blog PION merupakan kepanjangan dari "PAI Online" sehingga peserta didik dapat mempelajari materi secara online, baik di sekolah mau pun di rumah.

Media pembelajaran ini memiliki konsep penyajian seperti blog. Media pembelajaran ini dibuat dengan template yang sudah tersedia di WordPress namun diubah dan disesuaikan oleh peneliti. WordPress merupakan sebuah Content Management System (CMS) yang sifatnya open source karena kemampuannya untuk dimodifikasi dan disesuaikan dengan kebutuhan penggunanya (Anasari, 2009; Komputer, 2015). WordPress juga berbasis kode sumber terbuka (open source), pengguna bisa memperoleh barisan kode-kode penyusun software 
WordPress tersebut secara bebas, sehingga bagi pengguna yang memiliki kemampuan dalam hal pemograman, dapat melakukan modifikasi sesuai dengan kebutuhan dan keinginan pengguna. (Komputer, 2015).

Blog PION akan berbentuk penjelasan mengenai materi muamalah yang disertai gambar pendukung. Gambar diharapkan dapat membantu pemahaman peserta didik. Blog ini dapat dimanfaatkan oleh peserta didik sebagai media untuk belajar secara mandiri.

Pembuatan Blog PION sebagai media pembelajaran berbasis blended learning dengan materi Muamalah untuk kelas XI di SMK Negeri 1 Cibinong ini melalui lima tahapan dalam Model ADDIE yaitu analisis (Analyze), desain (Design), pembuatan (Development), implementasi (Implement), dan evaluasi (Evaluate).

Tahap pertama yang dilakukan yaitu analisis. Tahap ini dilakukan dengan cara menganalisis kurikulum, media dan model pembelajaran, serta materi yang digunakan dalam pembelajaran Pendidikan Agama Islam dan Budi Pekerti di SMK Negeri 1 Cibinong. Kurikulum yang digunakan yaitu kurikulum 2013.

Media pembelajaran Pendidikan Agama Islam dan Budi Pekerti yang digunakan dalam pembelajaran di SMK Negeri 1 Cibinong biasanya menggunakan Power Point sebagai pendukung penjelasan materi dan video yang berkaitan dengan pelajaran yang sedang dibahas.

Proses pembelajaran Pendidikan Agama Islam dan Budi Pekerti di sekolah ini, umumnya menggunakan; model pembelajaran teacher centered dengan metode ceramah, model pembelajaran student centered dengan metode diskusi, debat, mind mapping, problem solving, serta drama, menerapkan beberapa games dalam pembelajaran seperti jigsaw dan media sort card, serta mendemonstrasian atau mempraktikkan suatu materi seperti praktik shalat dan memandikan jenazah. Berdasarkan paparan tersebut, maka selama ini pembelajaran Pendidikan Agama Islam dan Budi Pekerti belum menerapkan blended learning dalam proses pembelajarannya.

Materi Muamalah dalam mata Pelajaran Agama Islam dan Budi Pekerti, dimuat dalam suatu bab yang berjudul Prinsip dan Praktik Ekonomi Islam. Materi yang disajikan dalam blog ini mengenai bagaimana ekonomi Islam diterapkan dalam kehidupan sehari-hari. Cakupan materinya meliputi; pengertian Muamalah, macam-macam Muamalah, perseroan (sirkah), perbankan, dan asuransi. Materi dalam Blog PION ini diambil dari buku pegangan siswa yang digunakan di SMK Negeri 1 Cibinong. Adapun buku yang digunakan adalah buku dari Kementrian Pendidikan dan Kebudayaan Indonesia tahun 2017 Kelas XI SMA//SMK/MAK. Selain itu, peneliti juga menambahkan referensi lain dari catatan kuliah, jurnal, dan website sebagai penunjang materi yang akan disajikan.

Tahap kedua yaitu tahap desain atau perancangan. Pada tahap perancangan, memuat kerangka media pembelajaran yang berisi storyboard. Storyboard memuat tampilan media pembelajaran berbentuk layout. Berikut 
ini perancangan dari beberapa halaman media pembelajaran:

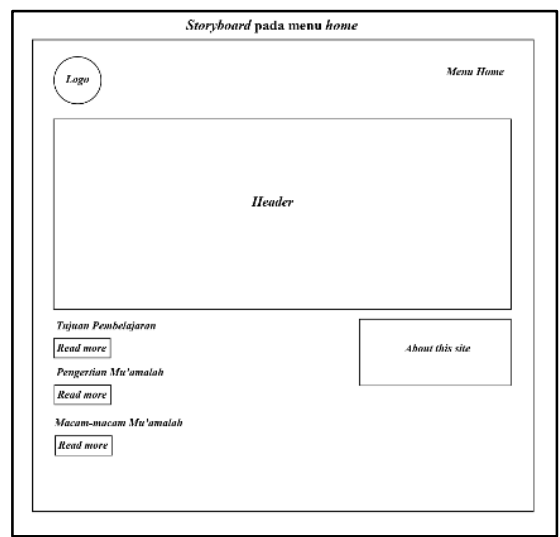

Gambar 1. Storyboard menu utama

Gambar tersebut merupakan layout untuk tampilan halaman utama Blog PION. Tampilan halaman utama tersebut berisi logo Blog PION, menu halaman utama (bome), header Blog PION, daftar materi yang akan dibuat dalam bentuk post, dan penjelasan singkat mengenai Blog PION itu sendiri.

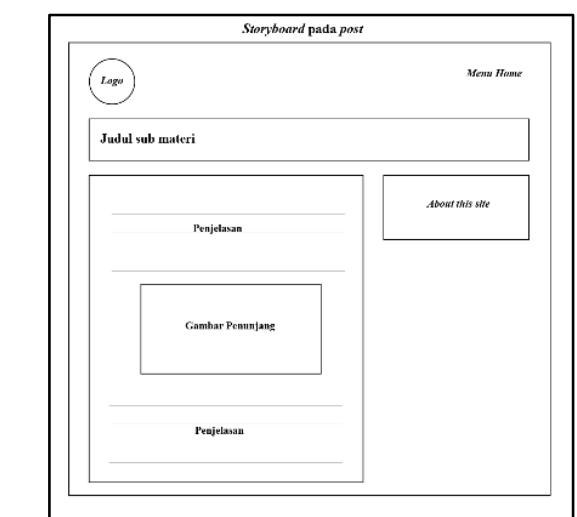

Gambar 2. Storyboard pada setiap post di Blog PION

Gambar tersebut merupakan layout untuk tampilan pada setiap post yang ada di Blog PION. Setiap halaman akan berisi $\log$ B Blog PION, menu halaman utama (home), judul sub materi, penjelasan mengenai materi yang dipelajari dan dilengkapi dengan gambar dengan rata tengah, kolom diskusi di bagian bawah materi, serta penjelasan singkat mengenai Blog PION.

Setelah storyboard dibuat, peneliti membeli domain kepada web developer. Domain yang dipilih oleh peneliti adalah web.id. Hal ini dikarenakan dari berbagai macam jenis ekstensi id, yang sesuai digunakan untuk kebutuhan Blog PION adalah domain web.id. Domain web.id ini dapat dipakai untuk keperluan institusi, organisasi, maupun pribadi dan persyaratan pendaftarannya hanya menggunakan KTP saja. Adapun dalam pembuatannya, Blog PION dibuat melalui WordPress.

Blog PION dapat diakses melalui laman https://pion.web.id/ . Blog PION memiliki sedikit tampilan yang berbeda ketika diakses menggunakan; laptop, tablet, dan telepon pintar.

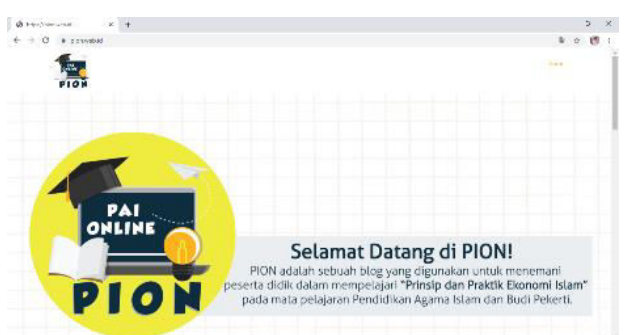

Gambar 3. Tampilan Blog PION pada layar bila diakses dengan laptop atau komputer

Gambar di atas merupakan salah satu contoh tampilan Blog PION bila akses oleh peserta didik atau visitor lainnya melalui laptop atau komputer. 


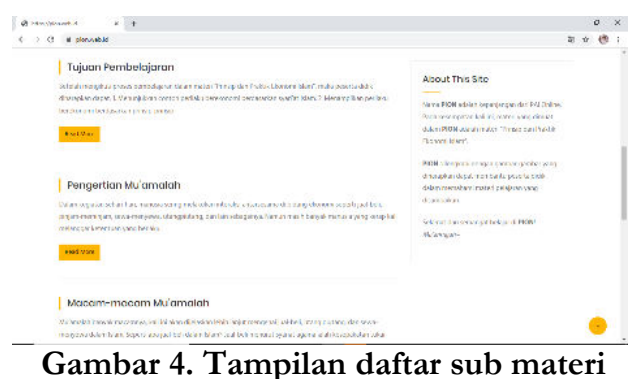

Tampilan daftar sub materi yang akan dipelajari oleh peserta didik adalah seperti yang terlihat pada Gambar 4.

Tahapan ketiga yaitu pembuatan Blog PION. Langkahlangkah yang dibutuhkan dalam membuat produk ini adalah:

1) Penentuan template blog. Template yang digunakan untuk Blog PION adalah Builderio versi 1.0.9 yang dibuat oleh Abileweb. Kemudian peneliti melakukan customize yaitu penyesuaian template yang telah diaktifkan sesuai dengan kebutuhan Blog PION. Kemudian menekan tombol publish jika telah selesah melakukan penyesuaian. Jika tombol publish berubah menjadi published, maka perubahan telah dipublikasi.

2) Membuat desain gambar penunjang. Desain gambar pada Blog PION dibuat dengan menggunakan aplikasi Adobe Illustrator CS6 dengan desain ukuran $22 \times 15 \mathrm{~cm}$. Background yang digunakan disesuaikan dengan materi yang dijelaskan; background warna biru untuk materi pengertian Muamalah, ungu untuk materi transaksi jual-beli dan khiyar, biru muda untuk materi riba, biru tua untuk materi utang-piutang, coklat untuk materi sewa-menyewa, biru langit untuk materi perseroan (syirkah), dan abu-abu untuk materi perbankan. Peneliti juga memasukkan teks pada desain gambar, teks tersebut berisi konten sesuai sub materi. Hal tersebut dapat dilihat dalam beberapa gambar di bawah ini:

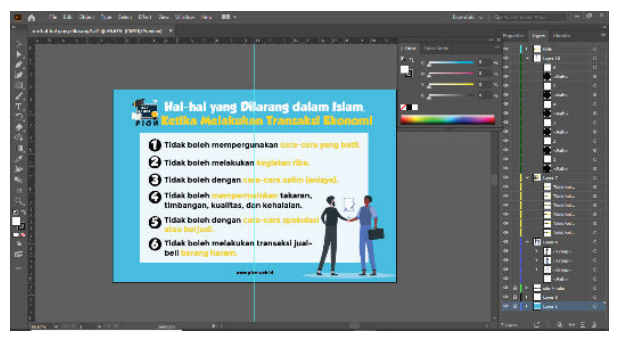

Gambar 5. Proses pembuatan gambar penunjang

Proses pembuatan gambar penunjang seperti yang tertera pada Gambar 5. terus berulang sebanyak 26 kali dengan konten yang berbedabeda. Setelah itu kemudian hasil desain yang telah dibuat, di-export dalam bentuk PNG. Adapun hasil akhir dari gambar penunjang tersebut adalah sebagai berikut:

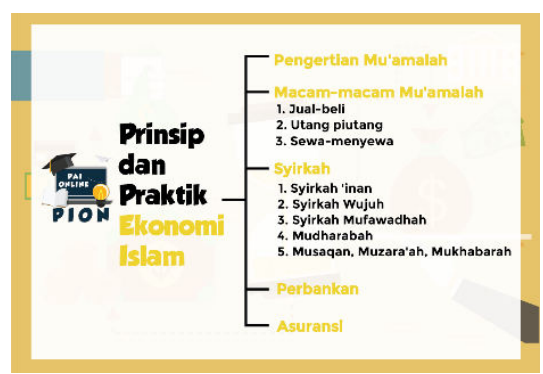

Gambar 6. Gambar pada post Tujuan Pembelajaran 


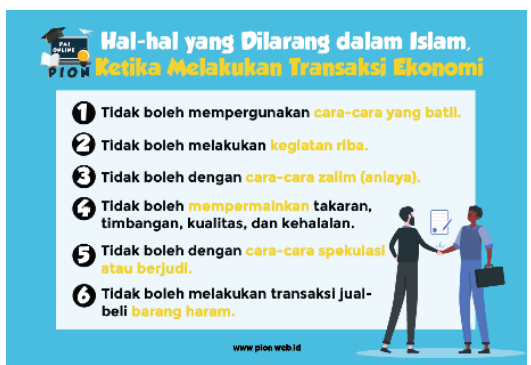

Gambar 7. Salah satu gambar pada sub materi "Pengertian Muamalah"

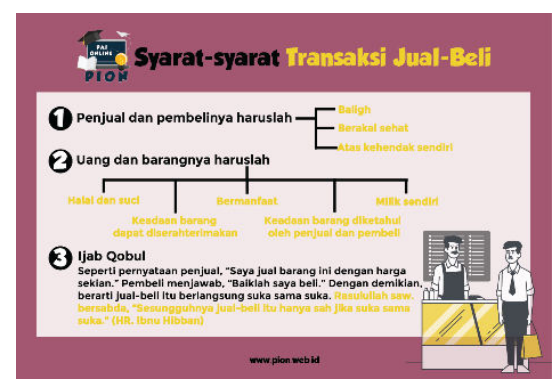

Gambar 8. Gambar penunjang pada pembahasan mengenai transaksi jualbeli

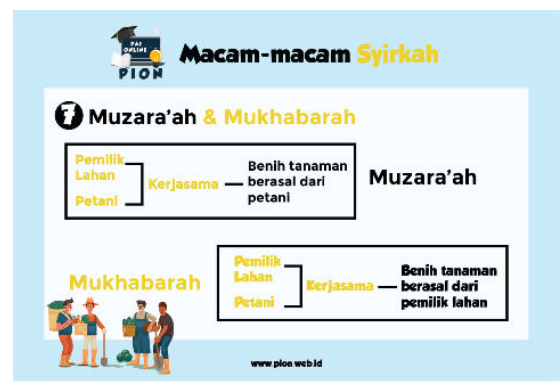

Gambar 9. Salah satu gambar penunjang pada pembahasan mengenai syirkah

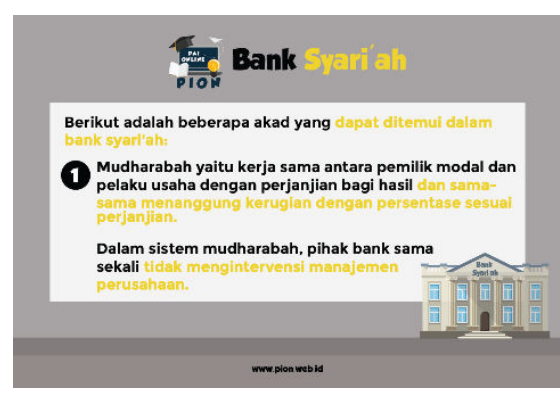

Gambar 10. Salah satu gambar penunjang pada pembahasan mengenai bank

Gambar 6 sampai dengan Gambar 10 merupakan contoh gambar penunjang yang terdapat dalam masing-masing post yang terdapat dalam Blop PION.

3) Membuat konten pada Blog PION. Materi yang sudah disiapkan oleh peneliti dalam Microsoft Word kemudian di-copy paste ke Blog PION, lalu disesuaikan dan dirapikan agar terlihat rapi dan proporsional

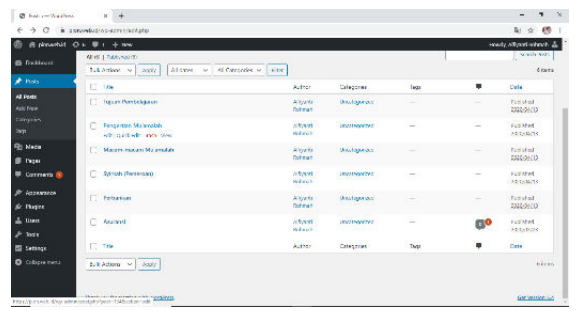

Gambar 11. Proses membuat konten langkah pertama; memilih post yang akan diisi dengan teks

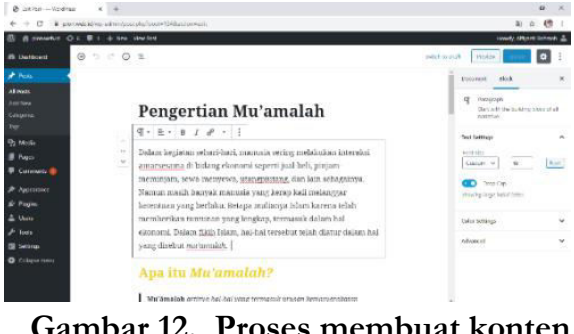

Gambar 12. Proses membuat konten langkah kedua; mengatur ukuran teks, tata letak, dan warna teks

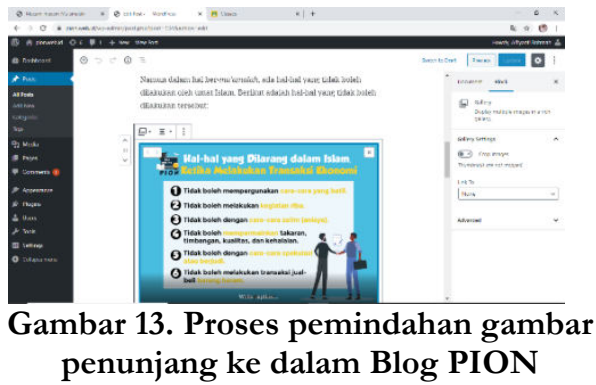

Proses pada Gambar 11., Gambar 12., Gambar 13. dilakukan secara berulang pada setiap post yang ada di Blog PION. Gambar 11. merupakan proses yang dilakukan ketika hendak membuat sebuah post atau melakukan pengeditan terhadap konten 
yang telah di-post. Gambar 12. cara mengunggah gambar yang akan merupakan proses ketika telah memilih dimasukkan ke dalam Blog PION. post mana yang akan dibuat atau diedit. Setelah itu, materi Muamalah dapat Gambar 13. merupakan proses diakses melalui www.pion.web.id oleh pemindahan gambar penunjang dengan peserta didik maupun visitor.

Tahapan keempat, yaitu implementasi Blog PION. Pada tahapan ini, dilakukan validasi oleh ahli materi dan ahli media kemudian dilakukan penilaian oleh guru mata pelajaran Pendidikan Agama Islam dan Budi Pekerti serta penilaian oleh peserta didik selaku sasaran produk. Data hasil validasi ahli materi dapat dilihat pada Tabel 1. berikut:

\begin{tabular}{|c|c|c|c|c|c|}
\hline No. & $\begin{array}{c}\text { Aspek } \\
\text { Validasi }\end{array}$ & $\begin{array}{c}\text { Jumlah } \\
\text { Penilaian }\end{array}$ & $\begin{array}{c}\text { Jumlah } \\
\text { Maksimal }\end{array}$ & Persentase & $\begin{array}{c}\text { Kriteria Kelayakan } \\
\text { Produk }\end{array}$ \\
\hline 1. & $\begin{array}{c}\text { Penyajian } \\
\text { Materi }\end{array}$ & 17 & 20 & $85 \%$ & $\begin{array}{c}\text { Layak dengan } \\
\text { predikat sangat baik }\end{array}$ \\
\hline 2. & Kebahasaan & 15 & 15 & $100 \%$ & $\begin{array}{c}\text { Layak dengan } \\
\text { predikat sangat baik }\end{array}$ \\
\hline 3. & Keterlaksanaan & 13 & 15 & $87 \%$ & $\begin{array}{c}\text { Layak dengan } \\
\text { predikat sangat baik }\end{array}$ \\
\hline & Jumlah & 45 & 50 & $90 \%$ & $\begin{array}{c}\text { Layak dengan } \\
\text { predikat sangat baik }\end{array}$ \\
\hline
\end{tabular}

Tabel 1. Hasil Perhitungan Nilai Validasi oleh Ahli Materi

Berdasarkan data hasil validasi materi yang terdapat dalam Blog PION oleh ahli materi, aspek penyajian materi, kebahasaan, dan keterlaksanaan memiliki kriteria layak dengan predikat sangat baik. Keseluruhan materi pada Blog PION memiliki persentase $90 \%$ dan memiliki kriteria layak namun perlu dilakukan revisi berupa menyesuaikan contoh pada setiap pembahasan dengan contoh yang mungkin terjadi pada keseharian peserta didik. Sedangkan hasil validasi ahli media akan dipaparkan dalam Tabel 2. berikut:

\begin{tabular}{|c|c|c|c|c|c|}
\hline No. & $\begin{array}{c}\text { Aspek } \\
\text { Validasi }\end{array}$ & $\begin{array}{c}\text { Jumlah } \\
\text { Penilaian }\end{array}$ & $\begin{array}{c}\text { Jumlah } \\
\text { Maksimal }\end{array}$ & Persentase & $\begin{array}{c}\text { Kriteria Kelayakan } \\
\text { Produk }\end{array}$ \\
\hline 1. & Tampilan & 17 & 25 & $72 \%$ & $\begin{array}{c}\text { Layak dengan } \\
\text { predikat baik }\end{array}$ \\
\hline 2. & Kebahasaan & 12 & 15 & $80 \%$ & $\begin{array}{c}\text { Layak dengan } \\
\text { predikat sangat baik }\end{array}$ \\
\hline 3. & Keterlaksanaan & 10 & 10 & $100 \%$ & $\begin{array}{c}\text { Layak dengan } \\
\text { predikat sangat baik }\end{array}$ \\
\hline \multicolumn{2}{|c|}{ Jumlah } & 39 & 50 & $78 \%$ & $\begin{array}{c}\text { Layak dengan } \\
\text { predikat baik }\end{array}$ \\
\hline
\end{tabular}

Tabel 2. Hasil Perhitungan Nilai Validasi oleh Ahli Media 
Berdasarkan data hasil validasi Blog PION berbasis blended learning oleh ahli media, aspek tampilan, kebahasaan, dan keterlaksanaan memiliki kriteria layak dengan predikat baik. Keseluruhan Blog PION memiliki persentase 78\% dan memiliki kriteria layak digunakan dengan revisi di bagian tampilan agar perlu memperhatikan layout pada gambar ukurannya tidak sama dan untuk pesan yang terlalu banyak pada gambar, perlu dikurangi sehingga keterbacaannya lebih baik.

Selanjutnya Blog PION diberi penilaian oleh salah satu guru mata pelajaran Pendidikan Agama Islam dan Budi Pekerti di SMK Negeri 1 Cibinong, berikut adalah hasil penilaiannya:

\begin{tabular}{|c|c|c|c|c|c|}
\hline No. & $\begin{array}{c}\text { Aspek } \\
\text { Validasi }\end{array}$ & $\begin{array}{c}\text { Jumlah } \\
\text { Penilaian }\end{array}$ & $\begin{array}{c}\text { Jumlah } \\
\text { Maksimal }\end{array}$ & Persentase & $\begin{array}{c}\text { Kriteria Kelayakan } \\
\text { Produk }\end{array}$ \\
\hline 1. & Tampilan & 21 & 25 & $84 \%$ & $\begin{array}{c}\text { Layak dengan } \\
\text { predikat sangat baik }\end{array}$ \\
\hline 2. & Kebahasaan & 12 & 15 & $80 \%$ & $\begin{array}{c}\text { Layak dengan } \\
\text { predikat sangat baik }\end{array}$ \\
\hline 3. & Keterlaksanaan & 9 & 10 & $90 \%$ & $\begin{array}{c}\text { Layak dengan } \\
\text { predikat sangat baik }\end{array}$ \\
\hline \multicolumn{2}{|c|}{ Jumlah } & 42 & 50 & $84 \%$ & $\begin{array}{c}\text { Layak dengan } \\
\text { predikat sangat baik }\end{array}$ \\
\hline
\end{tabular}

\section{Tabel 3. Hasil Penilaian oleh Guru}

Hasil penilaian oleh guru dijabarkan dalam Tabel 3, maka hasil perhitungan persentase sebesar 84\% dan termasuk dalam kategori sangat baik dari setiap aspeknya. Selanjutnya uji implementasi blog dilakukan oleh lima peserta didik kelas XI di SMK Negeri 1 Cibinong. Hasil uji implementasi blog kepada peserta didik dapat dilihat pada Tabel 4.

\begin{tabular}{|c|c|c|c|c|c|}
\hline No. & $\begin{array}{c}\text { Aspek } \\
\text { Validasi }\end{array}$ & $\begin{array}{c}\text { Jumlah } \\
\text { Penilaian }\end{array}$ & $\begin{array}{c}\text { Jumlah } \\
\text { Maksimal }\end{array}$ & Persentase & $\begin{array}{c}\text { Kriteria Kelayakan } \\
\text { Produk }\end{array}$ \\
\hline 1. & Tampilan & 108 & 125 & $86 \%$ & $\begin{array}{c}\text { Layak dengan } \\
\text { predikat sangat baik }\end{array}$ \\
\hline 2. & Kebahasaan & 44 & 50 & $88 \%$ & $\begin{array}{c}\text { Layak dengan } \\
\text { predikat sangat baik }\end{array}$ \\
\hline 3. & Keterlaksanaan & 65 & 75 & $87 \%$ & $\begin{array}{c}\text { Layak dengan } \\
\text { predikat sangat baik }\end{array}$ \\
\hline & Jumlah & 217 & 250 & $87 \%$ & $\begin{array}{c}\text { Layak dengan } \\
\text { predikat sangat baik }\end{array}$ \\
\hline
\end{tabular}

Tabel 4. Hasil Uji Implementasi Blog pada Peserta Didik 
Hasil uji implementasi blog pada peserta didik dijabarkan dalam Tabel 4., maka hasil perhitungan persentase sebesar $87 \%$ dan termasuk dalam kategori sangat baik dari setiap aspeknya. Selain itu, peneliti juga melakukan wawancara pada Senin, 8 Juni 2020. Wawancara dilaksanakan setelah peserta didik melakukan uji implementasi. Peserta didik bernama Kuntho berpendapat bahwa Blog PION bisa membuatnya tertarik membaca dengan tampilan Blog PION yang menarik dan disertai dengan gambar atau pemaparan yang jelas sehingga lebih mudah untuk dipahami. Kuntho juga berpendapat bahwa banyak blog yang melakukan clickbait sehingga judulnya tentang materi namun kontennya berbeda dengan judul. Berbeda dengan Blog PION; adanya kesesuaian antara judul dengan konten sehingga membantunya mempelajari materi yang tertinggal saat Prakerin.

Peserta didik bernama Syeh Adi berpendapat bahwa Blog PION sangat membantu dalam pembelajaran karena sering dibaca ketika sehabis pulang dari Prakerin. Selain itu, dari segi tampilan Blog PION ini simpel dan rapi sehingga tidak bosan untuk dibaca. M. Rizky juga berpendapat bahwa Blog PION membantunya dalam memperlajari materi yang tertinggal karena materi penjelasannya lengkap, jelas, dan padat. M. Rizky juga mengaku sejauh ini materi yang ada dalam Blog PION masih bisa dicerna dengan baik. Sedangkan $M$. Sadam beranggapan bahwa Blog PION membantu dalam pembelajaran karena isi yang terdapat pada Blog PION seperti sudah dirangkum sehingga memudahkan untuk dipahami.

Semua peserta didik yang diwawancarai oleh peneliti beranggapan bahwa Blog PION tidak menghabiskan kuota internet yang terlalu banyak. Peserta didik juga memberi masukan agar Blog PION ini dikembangkan lagi dan memuat materi yang lebih banyak sehingga tidak hanya materi muamalah saja.

Tahapan kelima, yaitu evaluasi. Tahapan ini dilakukan revisi dengan mempertimbangkan masukan dari ahli materi dan ahli media. Pada tahap ini pula ditinjau mengenai kelebihan dan kekurangan Blog PION. Kelebihan dari produk media pembelajaran ini yaitu dapat diakses dengan mudah oleh peserta didik. Produk ini juga dikemas dengan bahasa yang sederhana dan gambar penunjang sehingga memudahkan peserta didik untuk memahami materi. Menumenu yang ada pada produk ini dibuat sederhana sehingga dapat memudahkan peserta didik dalam mengoperasikan produk ini. Konten yang dimuat dalam produk ini juga sengaja dibuat agak ringan agar tidak terlalu menghabiskan kuota data peserta didik. Selain itu, peserta didik juga dapat langsung berkomentar pada kolom komentar yang tertera di setiap post sub materi jika ada yang kurang dimengerti, peserta didik yang lain juga dapat melihat atau menjawab pertanyaan temannya sehingga peserta didik yang satu dengan yang lainnya dapat sekalian berdiskusi.

Kelemahan produk ini adalah tidak dapat diakses jika peserta didik tidak memiliki kuota data internet karena produk ini hanya dapat diakses melalui internet. Namun dapat diatasi dengan menggunakan WiFi sekolah atau dapat diakses bersama-sama dengan peserta didik lainnya jika berada di sekolah. 


\section{KESIMPULAN}

Penelitian dan pengembangan ini menggunakna tahap Analyze, Deisgn, Development, Implement, dan Evaluate (ADDIE) dalam pembuatan Blog PION sebagai media pembelajaran berbasis blended learning pada materi Muamalah kelas XI di SMK Negeri 1 Cibinong.

Tahapan pertama yaitu analisis. Sebelum pembuatan blog PION, peneliti melakukan analisis terhadap kurikulum, media dan model pembelajaran, dan materi yang perlu dipelajari oleh peserta didik. Kurikulum yang digunakan di SMK Negeri 1 Cibinong adalah kurikulum 2013, materi Muamalah kelas XI dikemas dalam bab Prinsip dan Praktik Ekonomi Islam. Cakupan materinya meliputi; pengertian muamalah, macam-macam muamalah, syirkah (perseroan), perbankan, dan asuransi.

Tahapan kedua yaitu desain. Desain Blog PION dilakukan dengan cara merancang dan menetapkan judul produk, membuat storyboard, serta membuat tampilan produk.

Tahapan ketiga adalah proses pembuatan. Proses pembuatan Blog PION diawali dengan mengembangkan blog berdasarkan materi yang telah dikaji dan rancangan yang telah dibuat. Blog PION dibuat melalui WordPress dengan domain web.id. Kemudian peneliti menambahkan gambar penunjang yang dibuat dengan aplikasi Adobe Illustrator CS6 untuk membantu peserta didik dalam memahami materi.

Tahapan keempat adalah implementasi. Implementasi Blog PION dilakukan dengan cara melakukan validasi materi dan media yang terdapat dalam
Blog PION. Hasil validasi materi dengan rata-rata penilaian sebesar 4,5 dengan kategori "Sangat Baik" dan hasil penilaian dari validasi media sebesar 3,9 dengan kategori "Baik". Setelah divaliadsi, maka dilakukan uji implementasi blog kepada guru dan peserta didik. Hasil dari angket penilaian guru yaitu sebesar 4,2 dengan kategori "Baik". Uji implementasi blog kepada 5 peserta didik di SMK Negeri 1 Cibinong. Hasil akhir dari uji implementasi blog ini adalah sebesar 87\% dengan kategori "Sangat Baik" dan dapat dinyatakan bahwa media pembelajaran Blog PION pada materi Muamalah ini layak digunakan.

Evaluasi dari Blog PION ini dilakukan dengan cara melakukan perbaikan terhadap materi dan media yang telah disarankan oleh pakar materi dan media serta menimbang apa saja kelebihan dan kekurangan Blog PION sebagai media pembelajaran.

\section{REFERENSI}

Anasari, T. (2009). Membuat Media Pembelajaran Pembuatan Blog Berbasis Multimedia Pada SMK Negeri 1 Gondang Sragen. 1(3), 57-66.

Chaidar, H. (2014). Pemanfaatan Teknologi Informasi dan Komunikasi dalam Pembelajaran di SMA Muhammadiyah Tarakan. Jurnal Kebijakan Dan Pengembangan Pendidikan, 2(2), 184-192.

Dwi Irmawati, Sriyono, A. B. S. (2012). Studi Eksperimen Pemanfaatan Blended Learning Model Berbasis Web Sebagai Sumber Belajar Geografi. Edu Geography, 1(2).

Komputer, W. (2015). Membuat Toko Online dengan Wordpress dan WP ECommerce. Elex Media Komputindo. 
https://books.google.co.id/books?i $\mathrm{d}=6 \mathrm{k} 1 \mathrm{JDwAAQBAJ} \&$ printsec $=$ fro ntcover $\& \mathrm{dq}=$ membuat + toko + onlin $\mathrm{e}+$ dengan + wordpress + dan $+w p+e-$ commerce\&hl $=$ en\&sa $=$ X\&ved $=0 \mathrm{ah}$ UKEwjpncfi67LnAhWXbX0KHS41 BaAQ6AEIKTAA \# $\mathrm{v}=$ onepage\&q =membuat toko online dengan wordpress dan wp ecommerce\& $\mathrm{f}=\mathrm{fa}$

Suhartono. (2017). Menggagas Penerapan Pendekatan Blended Learning Di Sekolah Dasar Subartono BLENDED LEARNING APPROACH INITLATING APPLICATION Instructional media such as books, globes, and other students are learning in Menggagas Penerapan Pendekatan Blended Learning Di. 